\title{
Pursuing novel molecular mechanisms and treatment strategies to enhance lung growth in neonatal chronic lung disease (CLD)
}

Miguel A Alejandre Alcazar, Affl Aff2

Corresponding Affiliation: Aff1

Mark Kaschwich, $\stackrel{\text { Affl }}{ }$

Stefanie Preuss, $\stackrel{\text { Affl }}{ }$

Robert Ertsey, $\stackrel{\text { Affl }}{ }$

Sana Mujahid,, Affl

Eva Rother, $\stackrel{\text { Aff2 }}{2}$

Katharina Dinger, $\stackrel{\text { Aff2 }}{,}$

Jörg Dötsch, $\frac{\text { Aff2 }}{\text { (1) }}$

Marlene Rabinovitch, $\frac{\text { Affl }}{\underline{A}}$

Richard Bland,, Aff1

ArticleInfo

\begin{tabular}{|c|c|}
\hline ArticleID & 70 \\
\hline ArticleDOI & $\mid$\begin{tabular}{|c}
$\mid 10.1186 / 2194-7791-2-S 1-A 30$
\end{tabular} \\
\hline ArticleCitationID & A30 \\
\hline ArticleSequenceNumber & 30 \\
\hline ArticleCategory & Meeting abstract \\
\hline ArticleFirstPage & 1 \\
\hline ArticleLastPage & 3 \\
\hline ArticleHistory & $\begin{array}{ll}\text { RegistrationDate } & : 2015-7-1 \\
\text { OnlineDate } & : 2015-7-1 \\
\end{array}$ \\
\hline ArticleCopyright & $\begin{array}{l}\text { Alejandre Alcazar et al.2015 } \\
\text { This article is published under license to BioMed Central } \\
\text { Ltd. This is an Open Access article distributed under the } \\
\text { terms of the Creative Commons Attribution License } \\
\text { (http://creativecommons.org/licenses/by/4.0), which permits } \\
\text { unrestricted use, distribution, and reproduction in any } \\
\text { medium, provided the original work is properly cited. }\end{array}$ \\
\hline
\end{tabular}

Aff1

Department of Pediatrics, Cardiovascular Institute, Stanford University, Stanford, CA, USA 
Department of Pediatrics and Adolescent Medicine, University of Cologne, Germany

Abstracts of the 51st Workshop for Pediatric Research

51st Workshop for Pediatric Research

Göttingen, Germany

16-17 April 2015

This supplement has not been sponsored.

Meeting abstracts

\section{Rationale}

Infants born prematurely or with intrauterine growth restriction (IUGR) are often afflicted with CLD, a debilitating disorder marked by diminished alveoli and lung micro-vessels. Despite advances in neonatology, CLD's incidence remains high and its prevention elusive. Mechanical ventilation (MV), high inspired $\mathrm{O}_{2}$, and IUGR can disrupt key signaling pathways, reduce cell survival and disrupt matrix elements, thus inhibiting lung growth [1-ㅜ].

Aims

(1) To define the impact of $\mathrm{MV}, \mathrm{O}_{2}$ and IUGR on lung structure and function in newborn rodents.

(2) identify altered signaling pathways of neonatal lung injury, and test novel treatment strategies.

(3) mechanistic studies to define how such aberrant signaling may impact cell survival in culture.

\section{Methods}

(1) Exposure of newborn mice to prolonged MV or hyperoxia; IUGR in rats induced by maternal low protein diet.

(2) Prolonged $\mathrm{MV}-\mathrm{O}_{2}$ in pups treated with a serine elastase inhibitor Elafin.

(3) Studies with mouse alveolar epithelial (AEC) and lung micro-vascular endothelial (LMVEC) cells.

\section{Results}

$\mathrm{MV}, \mathrm{O}_{2}$, and IUGR inhibit alveolar and micro-vessel formation and disrupt matrix components in lung, resulting in reduced respiratory system compliance and increased airway resistance. TGF $\beta$ signaling is disrupted after $\mathrm{MV}, \mathrm{O}_{2}$, and IUGR which adversely affects homeostasis of AEC and LMVEC, contributing to impaired lung growth with disordered lung matrix. Moreover, $\mathrm{MV}-\mathrm{O}_{2}$ inhibited EGF-receptor activation and reduced Krüppel-like factor 4 (Klf4), a regulator of cell differentiation and survival. We identified this novel pEGFR-Klf4 axis as a key regulator of AEC survival, and discovered that pEGFR-Klf4 signaling is protected by treatment with Elafin during $\mathrm{MV}_{2} \mathrm{O}_{2}$.

\section{Conclusion}

These results identify critical pathways that can impact lung growth arrest, as seen in CLD, and uncover novel mechanisms that could promote alveolarization, thus pointing the way toward new treatments to improve the outcomes of infants with CLD.

\section{References}

1. Hilgendorff A, Parai K, Ertsey R, Navarro EF, Jain $\mathrm{N}$, Carandang $\mathrm{F}$, et al.: Lung matrix and vascular remodeling in mechanically ventilated elastin haplo-insufficient (EIn+/-) newborn mice. Am J Physiol Lung Cell Mol Physiol 2014,308(5):L464-L478.

2. Alejandre-Alcázar MA, Michiels-Corsten M, Vicencio AG, Reiss I, Ryu J, de Krijger RR, et al.: TGF-beta signaling is dynamically regulated during the alveolarization of rodent and human lungs. Dev Dyn 2008,237(1):259-269. 10.1002/dvdy.21403 
3. Alejandre Alcázar MA, Kwapiszewska G, Reiss I, Amarie OV, Marsh LM, Sevilla-Pérez J, et al.: Hyperoxia modulates TGF- $\beta$ /BMP signaling in the neonatal lung: implications for the pathogenesis of bronchopulmonary dysplasia. Am J Physiol Lung Cell Mol Physiol 2007,292(2):L537-L549.

4. Alejandre Alcázar MA, Morty RE, Lendzian L, Vohlen C, Oestreicher I, Plank C, et al.: Inhibition of TGF- $\beta$ Signaling and Decreased Apoptosis in IUGR-Associated Lung Disease in Rats. PLoS One 2011,6(10):e26371.. 10.1371/journal.pone.0026371

5. Alejandre Alcázar MA, Östreicher I, Appel S, Rother E, Vohlen C, Plank C, Dötsch J: Developmental regulation of Stat3-mediated inflammation: the missing link between intrauterine growth restriction and pulmonary dysfunction? $J$ Mol Med 2012,90(8):945-957. 10.1007/s00109-012-0860-9

6. Alejandre Alcázar MA, Dinger K, Vohlen C, Rother E, Plank C, Dötsch J: Prevention of postnatal hyperalimentation protects against disrupted TGF- $\beta$ and IL-6 signaling in Lungs after IUGR. $J$ Nutr 2014. 